\title{
English Language Teaching in Turkey in the 1960s: Plus ça change...?
}

1960’lar Türkiyesinde İngilizce Öğretimi: Var mı Değişen Bir Şey?

Ali Fuad Selvi

Middle East Technical University Northern Cyprus Campus

\begin{abstract}
The 1960s have witnessed a series of developments that paved the way to the tremendous growth and expansion in English Language Teaching (ELT) around the world. The purpose of this article is to portray a local snapshot of ELT in Turkey, both as an activity and a profession, in light of the global trends and developments. More specifically, the article opens with a broader look at the role and status of English in the country during this period. It is followed by examining what it meant to teach and be a teacher of English at the time. The discussion ends with establishing a set of connections to the current state of ELT in the local context. Finally, it is argued that the specific problems of ELT (e.g., lack of quality in pre-/in-service teacher education, recruitment methods and practices, physical conditions and infrastructure, teachers' language proficiency, insufficient competency in developing/adapting instructional materials, inconsistency in terms of instructional practices, and lack of sustainable mentoring and appraisal practices) remain somewhat stable since the 1960s.

Keywords: English, language teaching, language teacher education, 1960s, Turkey

Öz

1960'lı yıllar, İngiliz Dili Öğretimi alanında dünya çapında muazzam büyüme ve genişlemeye giden yolu açan bir dizi gelişmeye tanık olmuştur. Bu makalenin amacı, küresel eğilimler ve gelişmeler ışığında hem bir faaliyet hem de bir meslek olarak İngiliz Dili Öğretimi'nin Türkiye'deki yerel bir görüntüsünü ortaya koymaktır. İngilizcenin ülkedeki rolüne ve durumuna daha geniş bir bakışla yaklaşan bu çalışma özellikle bu dönemde İngilizce öğretmek ve öğretmeni olmanın ne anlama geldiğini incelemekte ve İngiliz Dili Öğretimi'nin yerel bağlamdaki mevcut durumuna bir dizi bağlantı kurmaktadır. Sonuç olarak, İngiliz Dili Öğretimi ile ilgili sorunların (hizmet öncesi/hizmet içi öğretmen eğitiminde kalite eksikliği, işe alım yöntem ve uygulamalarındaki sorunlar, fiziksel koşullar ve altyapı problemleri, öğretmenlerin dil yeterliliği, öğretim materyallerini geliştirme/uyarlamada yetersizlikler, öğretim uygulamaları açısından tutarsızlıklar ve sürdürülebilir mentorluk ve değerlendirme uygulamalarının eksikliği gibi) 1960’lı yıllardan bu yana büyük ölçüde sabit kaldığı iddia edilmektedir.
\end{abstract}

Anahtar Kelimeler: İngilizce, dil öğretimi, öğretmen eğitimi, 1960lar, Türkiye

\section{Introduction}

The decade of the 1960s (commonly referred to as "the Sixties") has been perhaps one of the most turbulent ones in world history in so many ways-wars and conflicts (e.g., Cold War, Vietnam, Arab-Israeli conflict), nuclear threats (e.g., the Cuban missile crisis), political divisions (e.g., the Berlin Wall), assassinations 
(e.g., John F. Kennedy, Martin Luther King Jr.), sociopolitical revolutions (e.g., decolonization, the cultural revolution in China, counterculture, and anti-war, civil rights, feminism, and gay rights movements), and space explorations (between the Soviet Union and the United States). The situation in Turkey was not drastically different ${ }^{1}$. Commenced with a coup d'état, this decade was marked by socioeconomic changes (e.g., class struggles, rapid and unplanned urbanization, student uprisings, trade unionism), cultural polarization (e.g., along various lines such as left vs. right, Turks vs. Kurds, Sunni vs. Alevi, laicism vs. Islamism), political radicalization (e.g., anti-Americanism and the militarization of the right- and left-wing), and a new agenda in foreign policy (e.g., the Cyprus issue) (Pekesen). Collectively, these events and trends encouraged scholars to refer to this decade as a period of "turmoil" (Pekesen, 2) or "social and political chaos" (Dinler, 10) in the country.

\section{The State of English Language Teaching in the 1960s}

Despite the bleak sociopolitical atmosphere around the world and in Turkey in the 1960s, English Language Teaching (ELT ${ }^{2}$ ), both as an activity and a profession, has experienced growth and expansion in terms of breadth, width, and professional stature during this time frame. Defined as an exciting period of "consolidation and renewal" (Howatt and Widdowson 241) or "the scientific period" (Howatt and Smith 85), this decade has witnessed remarkable progress in addressing the growing interest in teaching and learning English.

From a methodological perspective, the practice of ELT was under the dominance of structural syllabus following the Situational Approach on the European side of the Atlantic and the Audio-lingual Method on the North American side. Eventually, with decentralization of teachers, recognition of learner as a whole and central aspect in the teaching-learning process, and realization of both the inadequacy of "situations" and the importance of real-life language use in/for communication, the traditional approach in ELT began to evolve towards a more communicative direction. The move away from decontextualized habit formation prioritizing patterns and structures to the meaningful use of the language in/for communication is regarded as a prominent conceptual and methodological shift.

There were at least three important trends that contributed to the scientific credentials of this decade. First, from an instructional perspective, the utilization of various technologies, including filmstrips, tape recorders, and English by television courses and language laboratories, during this period, created an interest in and opportunities for enhancing ELT practices. As Howatt and Widdowson argue, these technologies encapsulated a set of advantages (e.g., a scientific spin, individualization of instruction, feedback mechanism, and expansion of listening materials) and disadvantages (e.g., cost, maintenance, and

\footnotetext{
${ }^{1}$ Readers interested in the political history of Turkey in the 1960s may refer to Ahmad (1977), Landau (2017), Kaynar (2017), Pekesen (2020), and Zürcher (2017).

2 Readers interested in the history of (English) language learning and teaching may refer to Howatt and Widdowson (2004), McLelland and Smith (2018), and Smith (2005).
} 
quality of materials, the artificiality of context and interaction, and integration into the curriculum). Second, from a teacher education perspective, the introduction of microteaching by Dwight W. Allen in 1968 as a controlled teacher education practice that enables teachers to apply and practice teaching skills under controlled conditions (e.g., a small group of (real) learners, shorter period, etc.) with a possibility of reflection through a recording. Finally, theoretical perspectives and emerged in the 1950s (e.g., generative grammar by Chomsky, applied linguistics) have expanded considerably and formed an essential dimension in the scientific bases of the theory and practice undergirding ELT.

The international mobility eased by the expansion of air travel during this period gave easier access for both teachers to travel to teach in different parts of the world (i.e., English as a foreign language) as well as for students (both from the Anglophone and non-Anglophone contexts) who choose the US and UK as prime destinations for a variety of purposes (e.g., personal visits, summer schools, special courses and tuition at institutions of higher education) (i.e., English as a second language) (Howatt and Widdowson 158). Therefore, it could be argued that these developments paved the way to the emergence of expansion, diversification, specialization, and professionalization of ELT practices. This understanding translates into bourgeoning of institutional structures through the establishment of professional associations such as Teachers of English to Speakers of Other Languages, Inc. (1966), Peace Corps in the US (1961), and Center for Applied Linguistics (1959) in the US and the Association of Teachers of English as a Foreign Language (1967) and British Association of Applied Linguistics (1967) in the UK. It should be noted that these organizations have not just made significant contributions to the growing professional stature of ELT but also created pathways for women in a profession dominated by the white, middle-class males mainly from Europe and the US for centuries (Thornbury).

The period of the 1960s is a remarkable era since both the field of ELT and the discipline of applied linguistics, in the form that we know them today, date from this period (Burns and Richards 2), despite an evident lack in epistemological base (Shulman). Preparing teachers as ELT professionals/specialists began with short certificate-bearing training programs designed to equip teachers with practical language teaching skills connected to the dominant teaching methods of the time (e.g., Audiolingualism and Situational Approach). Since then, teacher education (and more specifically, English/second language teacher education) has witnessed an exponential growth in terms of research establishing it as a fertile academic discipline in its own right, academic programs (pre-service programs leading to certification), continuing professional development (inservice programs), and standards-based quality control and assurance mechanisms (e.g., guidelines, standards, certification, and accreditation). 


\section{English and English Language Teaching in Turkey: The 1960s}

In an attempt to portray a multifaceted picture of the local context ${ }^{3}$ under the influence of global trends and developments described earlier, this section draws upon three interrelated discussions. It begins with a broader look at the role and status of English in the country during this period and is followed by examining what it meant to teach and be a teacher of English at the time.

\section{The role and status of English}

Turkey, which followed a policy of neutrality throughout World War II, made a strategic sociopolitical decision and joined the capitalist and anti-Communist Western Bloc in the newly established bipolar world led by the United States. This shift in axis and adoption of the American idea(l)s in the post-war new world order manifested itself in the form of growing influence through economic aids and programs (e.g., Truman Doctrine, Marshall Aid, Ford Foundation) and accession to major international political (e.g., European Union ${ }^{4}$ ), economic (e.g., World Bank in 1947, IMF in 1947), and military organizations (e.g., NATO in 1947) predominantly led by the United States. Coupled with the global linguistic winds of change in favor of the English as a lingua franca, these political developments transformed the foreign language landscape in Turkey, which had been under the influence of Arabic, Persian, German and French for a long time (see Figure 1 below).

Fig 1. The order of importance of foreign languages in Turkey (adapted from Demircan 116)

\begin{tabular}{|c|c|c|c|c|}
\hline Before 1773 & 1773-1923 & $1923-1950$ & $1950-1980$ & After 1980 \\
\hline \multicolumn{5}{|l|}{ Arabic } \\
\hline \multicolumn{5}{|l|}{ Persian } \\
\hline \multirow[t]{3}{*}{ Turkish } & French & & & \\
\hline & English & & & \\
\hline & German & & & \\
\hline
\end{tabular}

The rise of the role, status, and importance of the English language in the country created an increasing demand towards the language and translating into the expansion of processes and structures (e.g., schools, programs, courses) to meet this demand.

\section{The role and status of English}

The state of English language teaching during the 1960s was primarily built upon the expansion and extension of trends and vision established in the

\footnotetext{
${ }^{3}$ Due to space limitations and with an intention to present a more focused discussion, the paper has been delimited by the period of 1960 s. However, interested readers may refer to Tezgiden Cakcak (2019) for the educational history of Turkey, and Güneş (2009) for the history of English education, and Doğançay-Aktuna (1998), and Selvi (2011) for sociolinguistic analyses of the local context.

${ }^{4}$ The relations with the European Union began in 1959, adopted an institutional framework with the Ankara agreement in 1963, took a concrete step with an application for membership in 1987; accession talks began 2005 and have stalled since 2016.
} 
previous decades. The adoption of English as the first foreign language to be taught in MoNE schools in 1955 served as a catalyst for expanding the ELT activities both in terms of breadth and depth.

\section{English-medium instruction (EMI)}

During this period, yabancl okullar 5 (foreign schools) (e.g., Robert College (1863), American College for Girls (1871), Üsküdar American Academy in 1876, St. Pauls Institute at Tarsus (1888)) continued their operations with an increased enrollment of students from Turkish/Muslim backgrounds. Originally established by foreigners, missionaries, and various ethnolinguistic minority communities (e.g., Greek, Armenian and Jewish), these schools served as inspiration, models, and motivation for foreign language and foreign medium instruction in the country ${ }^{6}$ and bourgeoning of Turkish private schools ${ }^{7}$ as "a symbol of transition from East to West," as characterized by Yahya Kemal (Somel 53 qtd. in Şimşek 211) (see Table 1 below).

Table 1

Total Number of Foreign Medium Instruction Secondary Schools (adapted from Demircan 119)

\begin{tabular}{|c|c|c|c|c|c|c|c|c|c|}
\hline \multirow{2}{*}{ Years } & \multicolumn{2}{|c|}{ Italian } & \multicolumn{2}{|c|}{ German } & \multicolumn{2}{|c|}{ French } & \multicolumn{2}{|c|}{ English } & \multirow{2}{*}{$\begin{array}{c}\text { GRAND } \\
\text { TOTAL }\end{array}$} \\
\hline & Public & Private & Public & Private & Public & Private & Public & Private & \\
\hline $\begin{array}{c}1960- \\
1961\end{array}$ & - & 2 & 1 & 3 & 1 & 7 & 6 & 8 & \\
\hline TOTAL & \multicolumn{2}{|c|}{2} & \multicolumn{2}{|c|}{4} & \multicolumn{2}{|c|}{8} & \multicolumn{2}{|c|}{14} & 28 \\
\hline $\begin{array}{c}1970- \\
1971\end{array}$ & - & 2 & 1 & 3 & 1 & 7 & 9 & 8 & \\
\hline TOTAL & \multicolumn{2}{|c|}{ (no c } & \multicolumn{2}{|c|}{$\begin{array}{c}4 \\
\text { (no change) }\end{array}$} & \multicolumn{2}{|c|}{$\begin{array}{c}8 \\
\text { (no change) }\end{array}$} & \multicolumn{2}{|c|}{$\begin{array}{c}17 \\
(21 \% \text { increase })\end{array}$} & $\begin{array}{c}31 \\
(11 \% \\
\text { increase })\end{array}$ \\
\hline
\end{tabular}

This understanding manifested itself in the establishment of English-medium public schools, including Türk Maarif Cemiyeti Yenişehir Lisesi (later renamed as Türk Eğitim Derneği Ankara Koleji, in 1951) and Maarif Bakanlığı Kolejleri (Maarif Colleges8, in 1955) in six different cities besides Istanbul and Ankara, based on the ideals of preparing "youth who knows the major world languages

\footnotetext{
5 Other terms used to describe these schools include gayrimüslim mektepleri (non-Muslim schools), misyoner okulları (missionary schools), protestan okulları (Protestant schools), and cemaat mektepleri or azınlık okulları (minority schools).

${ }^{6}$ It should be noted that English was not the only language taught or adopted as a medium of instruction in these educational institutions (e.g., Schools such as Lycée Français Privé SaintBenoît (1783) and Notre dame de Sion Istanbul (1856) adopted French, Liceo Scientifico "Galileo Galilei" Di Istanbul (1870) adopted Italian, Deutsche und Schweizer Schulegemeinde zu Constantinople (1868) adopted German, just to name a few.

${ }^{7}$ Readers interested in the history of Turkish private schools may refer to Şimşek (2014) for the late-Ottoman era, and Uygun (2003) for both pre-Republican and Republican eras.

8 Renamed as Anadolu Lisesi (Anatolian High School) in 1975, these schools have served as the backbone of the English-medium instruction in the country until the early 2000s.
} 
properly and how to utilize scientific studies extensively" (TBMM 1). The linguistic division of labor in these schools required the adoption of Turkish in social sciences courses (e.g., geography, sociology, history) and English in natural and formal science courses (e.g., science and mathematics). In order to be able to maintain this practice, these schools introduced compulsory year-long intensive academic language preparation period (known as hazırlı yll or preparatory year) - a model that is still adopted both in secondary and tertiary education even today. The number of students attending these schools (see Table 2 below) has constantly and consistently increased throughout the 1960s and beyond.

Table 2.

The Total Number of Students Instructed in a Foreign Language in Secondary Schools (adapted from Demircan 102)

\begin{tabular}{|c|c|c|c|c|c|c|c|}
\hline \multirow{2}{*}{ Years } & \multicolumn{2}{|c|}{ German } & \multicolumn{2}{|c|}{ French } & \multicolumn{2}{|c|}{ English } & \multirow{2}{*}{ GRAND TOTAL } \\
\hline & Middle & High & Middle & High & Middle & High & \\
\hline 1950-1951 & 285 & 43 & 4,046 & 110 & 2,532 & 125 & \\
\hline TOTAL & \multicolumn{2}{|c|}{328} & \multicolumn{2}{|c|}{4,156} & \multicolumn{2}{|c|}{2,657} & 7,141 \\
\hline $1960-1961$ & 3,233 & 144 & 4,619 & 337 & 8,505 & 1,144 & \\
\hline TOTAL & \multicolumn{2}{|c|}{3,377} & \multicolumn{2}{|c|}{4,956} & \multicolumn{2}{|c|}{9,649} & $\begin{array}{c}17,982 \\
(152 \% \text { increase })\end{array}$ \\
\hline 1970-1971 & 3,005 & 371 & 5,251 & 424 & 14,711 & 6,502 & \\
\hline TOTAL & \multicolumn{2}{|c|}{3,376} & \multicolumn{2}{|c|}{5,675} & \multicolumn{2}{|c|}{21,213} & $\begin{array}{c}30,264 \\
\text { (68\% increase) }\end{array}$ \\
\hline
\end{tabular}

\section{English-medium instruction (EMI)}

Even though the symbolic value and importance attached to foreign languages (and particularly English) since the 1950s-60s have shown a steady upward trend in the country, the translation of these ideas into sustainable practices in the national education curricula (especially at the secondary level) was somewhat limited and exhibited a volatile and downward trajectory. In this paradoxical picture, foreign language courses in public high schools comprised $14 \%$ of the curriculum (a total of 15 hours throughout the three years) in the 1960s (MoNE qtd. in Güneş 23).

Tremendous increases in enrollment rates (see Table 3 below) and interest towards learning English and the insufficiency of physical (e.g., overcrowded classrooms), instructional (e.g., lack of high-quality instructional materials), and human (e.g., lack of qualified teaching workforce) infrastructure paved the way to the opening of a new chapter in English language education in the countrythe private sector. With the adoption of the 1961 constitution (see Article 21) and the Özel Öğretim Kurumları Kanunu (Law No. 625 on Private Educational 
Institutions), private schools (Turkish ${ }^{9}$ and others) and dershaneler (private tutoring centers) gained legal status and recognition under the supervision and inspection of the state (Uygun 115). These developments in the 1960s could be regarded as the first formal steps towards institutionalization of privatization of education in the country, which created a brand-new line of development for English language teaching practices in the local educational system (i.e., a total of 44 schools by the end of 1960s, according to Dikmen 9 qtd. in Uygun, 2003 114).

Table 3

Total Number of Students Learning a Foreign Language in Secondary Schools (adapted from Demircan 102)

\begin{tabular}{cccccc}
\hline Years & German & French & English & Arabic & TOTAL \\
\hline $1950-1951$ & 5,612 & 79,208 & 48,434 & -- & 133,254 \\
$1960-1961$ & 30,504 & 155,824 & 217,926 & 4,548 & 408,802 \\
& $(443 \%$ increase $)$ & $(97 \%$ increase $)$ & $\begin{array}{c}(350 \% \\
\text { increase })\end{array}$ & & $(207 \%$ increase $)$ \\
$1970-1971$ & 116,124 & 293,057 & $\begin{array}{c}840,848 \\
(285 \%\end{array}$ & $\begin{array}{c}49,308 \\
(984 \%\end{array}$ & $\begin{array}{c}1,299,327 \\
\text { increase })\end{array}$ \\
& $(280 \%$ increase $)$ & $(217 \%$ increase $)$ \\
\hline
\end{tabular}

English education was not only limited by middle and high schools but also found itself a place in specialized institutions such as klz enstitüleri (girls institutes), ticaret meslek liseleri (vocational schools for commerce), öğretmen okulları (teacher training schools) and imam-hatip liseleri (imam and preacher high schools) (Güneş, 2009). By the end of the decade (1969-1970), the total number of students taking English courses in public and private institutions reached 462,661 in middle schools and 138,306 in high schools (State Institute of Statistics 132 as qtd. in Güneş 88).

The instructional materials (often equated to coursebooks) used in public secondary schools during the 1960s (see Table 4 for a summary) were dominated mainly by A Direct Method English Course by Edward Vivian Gatenby, who worked in Turkey (1944-1952) and held various positions such as a "linguistic adviser" for the British Council and a Professor of Pedagogy and Head of the English Department at the Gazi Institute of Education and a Professor of English at Ankara University. Other notable titles used during this time include The Oxford English Course by Lawrence Faucett in public schools.

\footnotetext{
9 Readers interested in the history of private schools may refer to Şimşek (2014), and Kalafat (2021) for the late Ottoman era, and Uygun (2003) and Yilmazlar (2007) for the Republican era.
} 
Table 4.

Textbooks Used in Middle and High Schools in 1960-1961 (MoNE 43) and 1969-1970 School Years (MoNE 155)

\begin{tabular}{|c|c|c|}
\hline \multicolumn{3}{|c|}{ Middle Schools } \\
\hline & 1960-1961 & 1969-1970 \\
\hline \multirow{4}{*}{$\begin{array}{c}\text { Year } \\
1\end{array}$} & Ingilizce Ders Kitabı I (Faucett) & Ingilizce Ders Kitabı I (Faucett) \\
\hline & A Direct Method English Course I (Gatenby) & A Direct Method English Course I (Gatenby) \\
\hline & English in Turkey I (Sevin and Ağıș) & A Direct Method English Course Orta I (Gatenby) \\
\hline & Temel İngilizce I (Özgür) & \\
\hline \multirow{4}{*}{$\begin{array}{c}\text { Year } \\
2\end{array}$} & İngilizce Ders Kitabı I (Faucett) & İngilizce Ders Kitabı I (Faucett) \\
\hline & A Direct Method English Course II (Gatenby) & A Direct Method English Course II (Gatenby) \\
\hline & English in Turkey II (Sevin and Ağıș) & A Direct Method English Course Orta II (Gatenby) \\
\hline & Temel İngilizce II (Özgür) & \\
\hline \multirow{4}{*}{$\begin{array}{c}\text { Year } \\
\mathbf{3}\end{array}$} & İngilizce Ders Kitabı II (Faucett) & İngilizce Ders Kitabı II (Faucett) \\
\hline & A Direct Method English Course II (Gatenby) & A Direct Method English Course II (Gatenby) \\
\hline & English in Turkey III (Sevin and Ağış) & A Direct Method English Course Orta III (Gatenby) \\
\hline & Temel Íngilizce III (Özgür) & \\
\hline
\end{tabular}

High Schools

1960-1961

Ingilizce Ders Kitabı II (Faucett)

Year A Direct Method English Course III (Gatenby)

Temel Íngilizce IV (Özgür)

Ingilizce Ders Kitabı III (Faucett)

Year A Direct Method English Course III (Gatenby)

A Direct Method English Course IV (Gatenby)

İngilizce Ders Kitabı III (Faucett)

Year

3

A Direct Method English Course IV (Gatenby)
1969-1970

\author{
Ingilizce Ders Kitabı II (Faucett) \\ A Direct Method English Course III (Gatenby) \\ A Direct Method English Course Lise I (Gatenby) \\ Ingilizce Ders Kitabı III (Faucett) \\ A Direct Method English Course III (Gatenby) \\ A Direct Method English Course Lise II (Gatenby) \\ Ingilizce Ders Kitabı III (Faucett) \\ A Direct Method English Course IV (Gatenby) \\ A Direct Method English Course Lise III (Gatenby)
}

By the end of the decade, the Board of Education of the MoNE began to provide a list of supplementary books to support and extend the English classes, such as The Tenses and Their Usage - Zamanlar ve Kullanışı (Şentürk), A New Method English for All (Ayral), İngilizce-Türkçe Konuşma Kılavuzu (Kök), Radyo ile İngilizce (Calling All Beginners) (Hicks), Turgut Lives in Turkey (Ege), just to name a few (MoNE 186). This decade marked the beginning of greater involvement and control over the coursebooks and supplementary books initially by individual local authors and by a commission of authors convened by the MoNE from 1971 onwards. Furthermore, several reference books were used by the students and teachers at primary and secondary schools (see Table 5 below). 
Table 5.

Reference Books Used in Primary and Schools in the 1969-1970 School Year (adapted from MoNE Dergisi 222)

\begin{tabular}{lc}
\hline \multicolumn{1}{c}{ Titles } & Author \\
\hline İngilizcenin Temelleri (Fundamentals of English) & Buluç \\
İngilizcede Fiiller ve Zamanlar (Verbs and Tenses in English) & Çakalır \\
İngilizce Konuşma Anahtarı (Key to Speak English) & Limasollu Naci \\
Ingilizce-Türkçe Sözlük (English-Turkish Dictionary) & Alaylığlu and Göndem \\
Oxford Progressive English for Adult Learners & Hornby \\
\hline
\end{tabular}

Even though these materials contributed to the diversification options available to English language learners and teachers and created an avenue for local language experts, they were loaded with grammar-based explanations with Turkish translations and drill-oriented mechanical practices, and therefore far from fostering communicative and functional aspects of the language (Demircan 136). Besides, no data, information, or justification were available with regards to selection (criteria), integration (access and use), and impact (related to student success) of these materials.

\section{English language teaching and English-medium instruction in higher education}

During this period, institutions of higher education adopted several models to implement English language teaching, which includes (a) the adoption of English as a medium of instruction (e.g., the higher education division of Robert College, METU), (b) the establishment of a year-long intensive English preparatory programs, and (c) a level-based supplementary English instruction throughout the undergraduate education. By the end of the decade, 49,784 students $(23,060$ at various faculties and 26,724 in vocational schools) received English instruction and made English the most popular foreign language at the tertiary level (State Institute of Statistics qtd. in Güneş 94).

The trend of adopting English as a medium of instruction was followed by the establishment of Orta Doğu Yüksek Teknoloji Enstitüsü (Middle East High Technology Institute, later renamed as Orta Doğu Teknik Üniversitesi, Middle East Technical University) (1956)—the nation's first English-medium public institution of higher education. Even though the Institute initially accepted students with sufficient proficiency in English to follow courses in respective academic programs, "English Language Preparatory Division" (ELDP) was established in 1961 in response to meet the great demand among the nation's brightest students who need advanced proficiency skills to begin their academic programs. Students completing a year-long intensive English program (consisting of 3 classes and a total of 25 hours per week) continued taking English courses in their first year depending on their proficiency levels-6 hours at the advanced level and 10 hours at the intermediate level (METU). Native- 
English speaking instructors, which comprised about half of the teaching workforce in both the English Language Preparatory School and the Freshman Division, served as the backbone of the instructional practices, even though most of them were employed on a contractual basis with attractive salaries (Çakır 12).

The instructional materials (i.e., coursebooks) in higher education during this time were under the heavy influence of the development of text-based language skills (reading comprehension and translation) (Güneș 99). The notable titles of this period included People, Places, and Opinions, by Donna Swain and Matilda Bailey, A Practical English Grammar by Agnes V. Martinet and Audrey Jean Thomson, Let's Write English by George E. Wishon and Julia M. Burks, and Advanced English Practice by B. D. Graver (Bear). The only exception to this focus was the 18-volume Spoken English for Turks by Sheldon Wise, Matthew Charles, Bruce Downing, Ralph Nash, Alan Ovenden, and Hikmet Sebüktekin working at Robert College in Istanbul and Gazi Institute of Education. These titles served as the instructional foundation of the curriculum followed in the English Language Preparatory Schools and the English Divisions of the Humanities Department at METU, Robert College, and other institutions that followed the same path, including Boğaziçi University (1971).

English language teaching landscape in higher education during this decade exhibited similarities with its predecessor-secondary education. More specifically, the inadequacy of language proficiency levels of university students (with the exception of METU and Robert College, and later Boğaziçi University), treatment of foreign language courses merely as a school subject, paucity of the qualified teaching workforce, access to high-quality foreign language curricula, instructional materials and practices, and lack of opportunities for communication and interaction in/with English-speaking communities were among the difficulties experienced in (and beyond) this period. When seen in tandem with heavy teaching loads, insufficiency of subject matter knowledge alone to be an effective language instructor (i.e., the need for pedagogical content knowledge), the status of the teaching profession(als) in the society, limited opportunities for professional development, absence of professional reward mechanisms, these factors created a bleak picture for ELT profession(als) in the country.

\section{English language teaching and English-medium instruction in higher education}

The growing interest in learning foreign languages, and particularly English, sparked interests and motivations to expand the teaching and learning of languages beyond the realm of formal education. During this decade, the state formally adopted foreign languages as a critical aspect of the competencies of state employees (bureaucrats, foreign service employees, etc.) and established Devlet Memurları Yabancı Diller Eğitim Merkezi (Foreign Language Center for State Employees) in 1970. The Turkish MoNE took this mission to the next level by establishing a series of units such as Ögretici Filmler Merkezi (Instructional 
Movie Center) in 1951, which included Radyo İle Eğitim Ünitesi (Education by Radio Unit) in 1962, Test Bürosu (Bureau of Testing) in 1952, Yabancı Diller Ögrretimini Geliştirme Merkezi (Center for the Improvement of Foreign Language Teaching) in 1972 (Kavaklı 31415). In partnership with Türkiye Radyo Televizyon Kurumu (Turkish Radio and Television Corporation), Film-Radyo ve Televizyonla Eğitim Merkezi (The Center for Education through Film, Radio, and Television) commenced broadcasting educational content through the national radio/television in 1968. Besides, the establishment of Devlet Planlama Teşkilatı (State Planning Agency) in 1960 and Türkiye Öğretmenler Sendikası (Teachers' Union of Turkey) in 1965 could be cited as ancillary developments contributing to systematic and organized future of education in the country and professionals therein (Okçabol 73).

The relations with the Council of Europe, which began in 1968, paved the way to a series of initiatives in the early/mid-1970s, including the development of a new generation of foreign language curriculum based on the Threshold Level for the secondary-level, coursebooks aligned with the Council's standards for language instruction (e.g., An English Course for Turks for English, Wir Lernen Deutsch for German, and Je Parle Français for French) and supplementary materials (e.g., student's book, teacher's book, workbook, visuals, tables/charts, filmstrips, discs, tapes, and records). The overarching aims and scope of this new instructional approach required a drastic move away from the traditional model emphasizing rote learning of decontextualized grammar structures to a new orientation based on exposure, comprehension, and production of the target language through audiovisually supported meaningful activities (Güneş 69).

The strategic alliance and partnership established between Turkey and the United States after World War II manifested itself in the teaching and teacher education scene in the country through reports written by more than 40 foreign education specialists (e.g., Roben J. Maaske on teacher education) (Marım and Sam 17), partnerships with American institutions (e.g., Peace Corps, Turkish Fulbright Commission) (Güçlü and Şahan 1892) and various acts of American philanthropy (e.g., Rockefeller Foundation, Ford Foundation, etc.) (Erdem and Rose 2000). To be more specific, a total of 1,201 Peace Corps volunteers (known as Barış Gönüllüleri) came to Turkey between 1962 and 1969, and a great majority of them ( $67 \%$ of the volunteers) worked as teachers of English, mostly (26\% of the volunteers) based in Ankara (Güçlü and Şahan 1892). In the same vein, the US Fulbright education commission offered scholarships to 139 teachers between 1951 and 1981 (Demircan 108). It should be noted that these programs (and their participants) have received considerable criticism on technical (e.g., pedagogical qualifications based on very short training programs, and a lack of support by the MoNE), ideological (e.g., a symbol of White saviorism and American exceptionalism, a threat against national security and intelligence, and propagating Christian evangelism), and personal (e.g., growing antiAmericanism/Westernism in the local context) grounds. Despite their contested nature, these programs and participants have certainly played an important role 
in (1) the local ELT scene, (2) the introduction of American ideals, values, lifestyle, and people (in a context with underdeveloped physical infrastructure and human resources and at a time with limited international interaction), and (3) developing a body of knowledge about Turkey and its people which were later utilized in academia upon their return to the United States.

\section{English language teacher education}

The glocal (both global and local) interest towards the English language, educational policies institutionalizing the provision of English instruction in state schools, and the introduction of institutions of secondary (e.g., Maarif colleges) and higher education (e.g., Middle East Technical University) adopting English-medium instruction have all contributed to the importance of the qualified workforce to meet the growing local demand. Foreign language teacher education practices in the newly established Turkish Republic started with the foundation of Ĕgitim Enstitüsü (Gazi Institute of Education) in 1926, whose pedagogy department branched out to foreign languages, including French (1941), English ${ }^{10}$ (1944), and German (1947) (Demircan 103). As the primary source of teacher preparation, these institutes have increased in numbers (5 in 1960 to 16 in 1978), and the duration of programs of study at these institutes was increased from two to three years in 1962 and eventually to four years in 1978 under a new name Yüksek Öğretmen Okulu (Higher Teacher School). Ultimately, these schools were reorganized under Faculties of Education and transferred to universities with the establishment of the Yüksekögretim Kurumu (Council of Higher Education) in 1982.

Lack of long-term educational planning and rapid, unsystematic, and uneven developments in student numbers pushed the governments to devise transient solutions 11 to meet this demand with a cadre of educators from various resources, including

(1) graduates of philology departments within Faculty of Letters,

(2) university graduates who completed A, B, and C levels in a foreign language,

(3) graduates of foreign language programs at the Institutes of Education,

(4) graduates of other programs at the Institutes of Education with an additional specialization in a foreign language

(5) individuals who passed a yeterlik sinavı (professional competency exam) occasionally administered by the MoNE,

\footnotetext{
10 The first cohort included a total of 10 students ( 8 female and 2 male students) and was led by Edward Vivian Gatenby as the head of the program, and Hadiye Sayron, John Bell, and Namdar Rahmi Karatay as faculty members (Okumuş Ceylan, 2014, 7).

${ }^{11}$ Similar transient solutions and shortcuts to teaching certification continued to expand and exist in the decades to come (e.g., night school programs, distance education (via postal mail), intensive training programs that lasted for 1-2 months, external examinations, etc.).
} 
(6) individuals who passed the ögrretmen muavinliği (teacher assistant) exam that was occasionally administered by the MoNE,

(7) individuals who obtained a teaching certificate by completing a training course offered by the MoNE

(8) individuals who spent time in Western countries to develop their knowledge and manners in accordance with Law No. 4489

(9) graduates of foreign private schools who were selected and appointed by school principals to serve as adjunct teachers

(10) graduates of ilköğretmen okulları (teacher training schools for primary education) who know a foreign language,

(11) the US nationals who serve as Peace Corps volunteers,

(12) foreign nationals or teachers who worked at Maarif colleges/Anatolian High Schools (Demircan 1988 106)

Relying on individuals from various backgrounds, experiences, and expertise to meet the growing need and demand for English teachers stood out as a shortterm solution prioritizing quantity over quality without any considerations of pedagogical skills, effectiveness, and sustainability in the long term. Considerable and unplanned increase in student numbers, scarcity of physical infrastructure (e.g., number of classrooms), dearth of the qualified workforce (e.g., teachers), the inadequacy of Institutes of Education in preparing qualified teachers, and lack of instructional resources (e.g., curriculum, instructional materials) have collectively made these solutions inevitable during this period. By the end of the decade, a total of 2,940 English teachers were working in various secondary institutions on a full- and part-time basis, while there was a need for an additional 1,293 teachers even though teachers had 24-30 contact hours per week (Küçükahmet as qtd. in Demircan 1988 107).

The history of in-service training in the country formally began with the establishment of Öğretmeni İşbaşında Yetiştirme Bürosu (The Bureau of Teacher Training on the Job) by the MoNE in 1960, which first evolved into Hizmet İçi Eğitim Daire Başkanlı̆̆ı (The In-Service Training Department) in 1975 and eventually into Öğretmen Yetiştirme ve Geliştirme Genel Müdürlüğü (The General Directorate of Teacher Training and Development) in 2011 (Kaya 185). The inservice training (lasting for 4-6 weeks) for English teachers was offered for the first time during the summer period of 1960, developed in consultation with the British Council and implemented by the MoNE officials. The tradition of sending professionals abroad for professional development, which started in the late Ottoman era, continued during this time. A selection of teachers from various fields and backgrounds were sent to Europe and the United States with the financial support provided by the Turkish MoNE, NATO, the Council of Europe, and the US Fulbright Commission (Nergis 184). 


\section{The State of English Language Teaching in the 1960s}

What has changed and remained the same in terms of the role and status of English and ELT - as an activity, a profession, and an area of scholarly inquiry? The trajectory of English in the local linguistic landscape was a complex interplay of push (the manifestation of English as a global lingua franca) and pull (English as a symbolic linguistic vehicle in the realization of Westernization idea(l) as a state ideology and policy of development) factors. The change of tides from French to English as the first foreign language to be taught in MoNE schools starting in 1955 officially marked the beginning of a new chapter in the foreign language teaching landscape in the country that still continues even to this date (and will continue in the foreseeable feature). Today, the use of the term "foreign language" synonymously with English reaffirms the undisputed status of English - a linguistic sine qua non for every educated citizen in the country (Selvi 186).

The rise of the US as a major political/economic power, global decolonization process, emergent technologies, the expansion of ELT activities, institutionalization of professionalism, and the rise of applied linguistics as a scientific base for priorities have collectively made the 1960s a remarkable decade for the ELT profession(als) around the world and Turkey was no exception. Since then, the academic base and professional scope of ELT in Turkey have expanded tremendously both in terms of depth and breadth. Today, English is the most widely taught foreign language and foreign medium of instruction across all levels from pre-K to doctoral levels. ELT professionals. English is also the most widely tested foreign language in the Yabancı Dil Sinavi (Foreign Language Exam) administered by the Ölçme, Seçme ve Yerleștirme Merkezi (Student Selection and Placement Centre). ELT professionals consistently comprise the lion's share of the foreign language teacher workforce at all levels of education, ranging from pre-kindergarten institutions to universities. In addition, there is still a great demand for ELT professionals, both on an adjunct and permanent basis.

The tremendous growth in the interest, breadth, and scope of ELT practices since the 1960s has not translated into viable results in terms of language proficiency. Even after receiving nearly 1,400 hours of English instruction between Year 2 and 12, the communicative abilities of students and teachers are far from the desired levels. Individuals taking the Yabancl Dil Testi (Foreign Language Test) section of the Yüksekögretim Kurumları Sinavı (Higher Education Institutions Exam) to study in English-related undergraduate programs scored an average of 31,467 out of 80 questions (ÖSYM). Similarly, individuals taking the Ögretmenlik Alan Bilgisi Testi (Teacher Field Knowledge Test) to serve as public school teachers scored an average of 35,612 out of 75 questions (ÖSYM). As a result, the 2020 iteration of the EF English Proficiency Index lists Turkey 69 out of 100 countries around the world (second from the bottom in Europe, after Azerbaijan) and labels it as a "low proficiency" country 
(English First). Thus, it could be concluded that the specific problems of ELT12 (including but not limited to lack of quality in pre-/in-service teacher education, recruitment methods and practices, physical conditions and infrastructure, teachers' language proficiency, insufficient competency in developing/adapting instructional materials, inconsistency in terms of instructional practices, and lack of sustainable mentoring and appraisal practices) remain somewhat stable since the 1960s (Coşkun Demirpolat 13). Over the years, responses to these problems by devising transient, unsubstantiated (e.g., recruitment of 40,000 native English-speaking teachers) or improvident (e.g., The FATiH project) solutions packaged as massive educational reforms which end up having a limited shelf life. This leads to the widespread use of the expression of yapboz tahtası (jigsaw puzzle) to define the educational system, in general, and ELT practices, in specific. More interestingly, changing demographics (e.g., Syrian refugee populations), adoption of new technologies (e.g., online teaching with

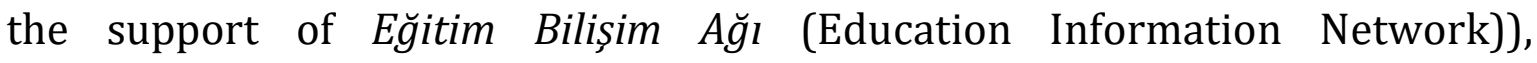
unprecedented challenges (e.g., emergency remote teaching due to COVID-19 pandemic), mushrooming of higher education institutions, equitable access to quality ELT practices (e.g., uncontrolled/unregulated privatization) will stand out as additional layers of friction in the future of ELT profession(als) as a whole.

Drawing our attention to the notions of criticality and sociocultural/historical factors, Joshua M. Bear's acute observations still hold true after nearly 40 years: "certain historical, cultural, and social factors...can not only help to illuminate the successes and failures of foreign language education in Turkey, but can also provide us with insights into ways to improve current practices" (28). Otherwise, we will find ourselves repeating the French writer Jean-Baptiste Alphonse Karr's widely-cited quote to describe the local ELT landscape in Turkey- "plus ça change, plus c'est la même chose" (the more things change, the more they stay the same).

\section{Acknowledgment}

This festschrift article is a humble tribute to Dr. Joshua M. Bear, my Newtonian Giant, who is more widely known as "Joshua Hoca," for his immense contributions to and long-lasting impact on me (both as an individual and as a scholar) and in the fields of ELT and applied linguistics. His teaching, research, and mentorship, spanning over more than five decades, have uncharted new directions and transformed the lives and everyday practices of thousands of individuals near and far. Therefore, his intellectual legacy and personal virtues continue to live on in the thoughts, words, and deeds of those of us who have

12 Over the years, scholars in ELT have investigated different aspects of the problems in ELT. These problems were beyond the scope of the current paper, and therefore have not been discussed in detail due to space limitations. Interested readers may refer to Bayraktaroğlu (2015), British Council/TEPAV (2013), Coşkun Demirpolat (2015), and Demirel (2016), among others. 
seen further by standing on his shoulders. To better understand him and his personal/professional journey as a scholar, I decided to offer readers and the wider ELT community a snapshot of Turkey's English language teaching and teacher education landscape in the 1960s-a time when he began his career in Turkey.

\section{Works Cited}

Ahmad, Feroz. Turkish Experiment in Democracy. Van Haren Publishing, 1977.

Bayraktaroğlu, Sinan. "Cumhuriyet'in 100. Yllına 8 Kala Üniversitelerde Yabancı Dilde ve Türkçe Eğitimde Yaşanan Sorunlar." Kebikeç, vol. 39, 2015, pp. 117-160.

Bear, Joshua M. "Historical Factors Influencing Attitudes Toward Foreign Language Learning in Turkey." Journal of Human Sciences of Middle East Technical University, vol. 1, 1985, pp. 27-36.

---. "Re: The Initial Stages of Your Journey in Turkey." Received by Ali Fuad Selvi, 2 May 2021. Personal communication.

British Council and TEPAV. Turkey National Needs Assessment of State School English Language Teaching. Mattek, 2013.

---. The State of English in Higher Education in Turkey: A Baseline Study. British Council, 2015.

Burns, Anne and Jack C. Richards. "Introduction: Second Language Teacher Education." The Cambridge Guide to Second Language Teacher Education, edited by Anne Burns and Jack C. Richards. Cambridge University Press, 2009, pp. 1-8.

Çakır, Abdulvahit. "Türkiye'de YÖK Öncesi ve Sonrası Yabancı Dil Eğitimi." Journal of Language Research, vol. 1., no. 1, 2017, pp. 1-18.

Coşkun Demirpolat, Başak. “Türkiye'nin Yabancı Dil Öğretimiyle İmtihanı: Türkiye'nin Yabancı Dil Öğretimiyle İmtihanı: Sorunlar ve Çözüm Önerileri." SETA Analiz, 131, 2015.

Demircan, Ömer. Dünden Bugüne Türkiye'de Yabancı Dil, Remzi, 1988.

Demirel, Özcan. Yabancı Dil Ögrretimi. Pegem Akademi, 2016.

Dikmen, Orhan. Özel Yüksek Okullar Meselesi. Cahit Matbaası, 1971.

Dinler, Mesut. "A Political Framework for Understanding Heritage Dynamics inTurkey (1950-1980)." Urban History, 2021, pp. 1-19. doi:10.1017/S096392682100016X

Doğançay-Aktuna, Seran. "The Spread of English in Turkey and its Current Sociolinguistic Profile." Journal of Multilingual and Multicultural Development, vol. 19, no. 1, 1998, pp. 24-39., doi:10.1080/01434639808666340.

English First. EF English Proficiency Index, 2020. https://www.ef.com/assetscdn/ WIBIwq6RdJvcD9bc8RMd/legacy/_/ /media/centralefcom/epi/downloads/f ull-reports/v10/ef-epi-2020-english.pdf

Erdem, Murat, and Kenneth W. Rose. "American Philanthropy in Republican Turkey: the Rockefeller and Ford Foundations." Milletlerarasl, 2000, pp. 001-27. doi:10.1501/intrel_0000000022.

Güçlü, Mustafa, and Ahmet Şahan. "An Evaluation of English Language Teacher Training in The Republic Period in Turkey from the Viewpoint of Historical Development." OPUS Uluslararası Toplum Araştırmaları Dergisi, vol. 9, no. 16, 2018, pp. 1883-902. doi:10.26466/opus.474395. 
Güneș, Bilal. 1945-1980 Arası Türkiye'de İngilizce Eğitimi. 2009. Süleyman Demirel Üniversitesi, Master's Thesis.

Howatt, Anthony P. R., and Widdowson, Henry G. A History of English Language Teaching. $2^{\text {nd }}$ ed., Oxford University Press, 2004.

Howatt, A. P. R., and Richard Smith. "The History of Teaching English as a Foreign Language, from a British and European Perspective." Language \& History, vol. 57, no. 1, 2014, pp. 75-95. doi:10.1179/1759753614z.00000000028.

Kalafat, Oğuz. Türkiye'de Özel Okullar Tarihi. Ankara, Akademisyen Kitabevi, 2021.

Kaya, Metin. “MEB Öğretmen Yetiştirme Genel Müdürlüğü'nün Hizmet İçi Eğitim Faaliyetleri: Katılımcllar, Eğitim Durumları, Eğitim Konuları." Trakya Eğitim Dergisi, 2020, pp. 205-15. doi:10.24315/tred.562063.

Kavaklı, Nurdan. Materials Development and Design Policies in English Language Teaching by Turkish MONE, 1923-2015. Elixir International Journal, vol. 81, 2015, pp. 31414-31419.

Kaynar, Mete Kaan. Türkiye'nin 1960’lı Yılları. İletişim Yayıncılık, 2017.

Landau, Jacob. Radical Politics in Modern Turkey (Routledge Library Editions: Turkey). 1st ed., Routledge, 2017.

Marım, Yüksel, and Rıza Sam. "1950-1960 Arası Amerikalı Uzman Raporları Bağlamında Türk Eğitim Sistemine Çizilen Yol Haritası.” Kaygı. Uludă̆ Üniversitesi Fen-Edebiyat Fakültesi Felsefe Dergisi, 2018. doi:10.20981/kaygi.411677.

METU. "The Foundation Years." Middle East Technical University School of Foreign Languages, http://ydyom.metu.edu.tr/en/foundation-years. Accessed 28 May 2021.

McLelland, Nicola, and Richard Smith. The History of Language Learning and Teaching II: 19th-20th Century Europe. Legenda, 2018.

MoNE. Tebliğler Dergisi. 1960, http://tebligler.meb.gov.tr/index.php/tuemsayilar/finish/23-1959/5024-1959-sayi-1038-1089-1959-22571

MoNE. Tebliğler Dergisi, 1969 http://tebligler.meb.gov.tr/index.php/tuemsayilar/finish/24-1960/5025-1960-sayi-1090-1133-1960-22572

Nergis, Ayşegül. "Foreign Language Teacher Education in Turkey: A Historical Overview." Procedia - Social and Behavioral Sciences, vol. 15, 2011, pp. 181-85. doi:10.1016/j.sbspro.2011.03.070.

Okçabol, Rıfat. Türkiye Eğitim Sistemi. Ütopya Yayınevi, 2005.

Okumuş Ceylan, N. A Brief History of English Language Teaching in Turkey. Pegem Akademi, 2014.

ÖSYM. 2020 Kamu Personel Seçme Sinavı Lisans Oturumlara Göre Aday Sayıları. 2020a, https://dokuman.osym.gov.tr/pdfdokuman/2020/KPSS/LISANS/sayisalbilgiler 22102020.pdf

ÖSYM. 2020 Yükseköğretim Kurumları Sınavı Sayısal Veriler. 2020b, https://dokuman.osym.gov.tr/pdfdokuman/2020/YKS/yks_sayisal_27072020. pdf

Pekesen, Berna. Turkey in Turmoil: Social Change and Political Radicalization During the 1960s. De Gruyter Oldenbourg, 2020, doi: 10.1515/9783110654509.

Sebüktekin, Hikmet. Yüksek öğretim Kurumlanmızda Yabancı Dil İzlenceleri. Boğaziçi Üniversitesi Yayınları, 1981. 
Selvi, Ali Fuad. "World Englishes in the Turkish Sociolinguistic Context." World Englishes, vol. 30, no. 2, 2011, pp. 182-99. doi:10.1111/j.1467971x.2011.01705.x.

Şimşek, Hüseyin. (2014). “Osmanlı Devletinde Özel Okullar ve İlk Türk Özel Okulunun Tarihçesine Dair Yeni Bilgiler" Bilig, vol. 68, pp. 209-30.

Smith, Richard. Teaching English as a Foreign Language, 1936-1961: Foundations of ELT. 1st ed., Routledge, 2005.

Shulman, Lee. "Knowledge and Teaching: Foundations of the New Reform." Harvard Educational Review, vol. 57, no. 1, 1986, pp. 1-21.

Somel, Selçuk Akșin (2001). The Modernization of Public Education in the Ottoman Empire (1839-1908): Islamization, Autocracy, and Discipline. Leiden, Brill, 2001.

State Institute of Statistics. Milli Eğitim Ístatistikleri Orta Öğretim 1965-67. Ankara, 1968.

TBMM. Tutanak Dergisi, 1954, https://www.tbmm.gov.tr/tutanaklar/TUTANAK/ TBMM/d10/c004/tbmm10004025.pdf

Tezgiden Cakcak, Yasemin. Moving beyond Technicism in English-Language Teacher Education: A Case Study from Turkey. Lexington Books, 2019.

Thornbury, Scott. "W is for women in ELT." An A-Z of ELT, 30 Jul. 2017, https://scottthornbury.wordpress.com/2017/07/30/w-is-for-women-in-elt/.

Uygun, Selçuk. "Türkiye'de Dünden Bugüne Özel Okullara Bir Bakiş (Gelişim Ve Etkileri)." Ankara Üniversitesi Ĕgitim Bilimleri Fakültesi Dergisi, 2003, pp. 001-14. doi:10.1501/egifak_0000000083.

Yılmazlar, Hakan. Türkiye'de Özel Okullarin Gelişimi (1923-1950). 2007. İstanbul University, Master's Thesis.

Zürcher, Erik-Jan. Turkey: A Modern History. Tauris, 2017. 